\title{
Prolactin Binding Analysis and Immunohistochemical Localization of Prolactin Receptor in Porcine Ovarian Cells
}

\author{
Maria SŁOMCZYŃSKA, Ewa GREGORASZCZUK, KaZIMIERz KOCHMAN* \\ AND STANisŁawa STOKŁOSOWA
}

Laboratory of Animal Endocrinology \& Tissue Culture, Department of Animal Physiology, Institute of Zoology, Jagiellonian University, 30-060 Krakow, Ingardena 6, Poland

* Institute of Animal Physiology \& Nutrition, Polish Academy of Sciences, 00-651 Jabłonna/Warszawa, Poland

\begin{abstract}
In the present study we searched for prolactin receptor (PRL-R) in porcine ovarian theca tissue (Tc) of small, medium and large follicles, as well as in early corpus luteum (ECL). The objectives of this investigation were: 1) comparison of the direct effect of PRL action on progesterone $\left(P_{4}\right)$ and estradiol $\left(E_{2}\right)$ secretion from Tc and ECL cells in culture with adequate effects caused by luteinizing hormone (LH). 2) detection of the presence and distribution of PRL-R in thecal tissue of porcine follicles and in ECL. Tissues were cultured as monolayers either in control M199 medium with calf serum or in medium either with PRL $(100 \mathrm{ng} / \mathrm{ml})$ or with $\mathrm{LH}(100 \mathrm{ng} / \mathrm{ml})$. After 2 days in vitro cultured media were assayed for steroid concentrations by radioimmunoassays. Content and distribution of PRL-R were evaluated by Scatchard analysis and by an immunohistochemical assay. Separated theca layers as well as fragments of ECL were excised on dry ice, homogenized, and incubated with [ ${ }^{125}$ I]-PRL. PRL stimulated $\mathrm{P}_{4}$ secretion from Tc 10 -fold versus controls. LH stimulated $\mathrm{P}_{4}$ secretion only 2.5 -fold. $\mathrm{E}_{2}$ secretion was stimulated by PRL 2.7-fold and by LH 2.4-fold. LH enhanced $\mathrm{P}_{4}$ secretion from ECL cells by $18 \%$ while PRL increased $\mathrm{P}_{4}$ secretion by as much as $73 \%$. Femtomol amounts of PRL-R protein were detected in theca tissues of medium and large follicles and also in ECL, which was in accordance with immunohistochemical results. The results showed for the first time the presence of PRL-R in porcine Tc and ECL.
\end{abstract}

Key words: Prolactin, PRL receptor, Immunohistochemistry, Ovary, Pig

(Endocrine Journal 48: 71-80, 2001)

Prolactin (PRL), a multifunctional protein hormone, is synthesized and secreted by lactotrophs of the anterior hypophysis. In mammals, target cells for PRL are found in a variety of organs, of which the ovary is one. PRL is best known for its action on mammary gland [1]. However, recent data have shown its involvement in growth and maturation of ovarian follicles and maintenance of luteal function in some

Received: August 16, 2000

Accepted: November 15, 2000

Correspondence to: Dr. Maria SŁOMCZYŃSKA, Laboratory of the Animal Endocrinology \& Tissue Culture, Department of Animal Physiology, Institute of Zoology, Jagiellonian University, 30-060 Kraków, Poland. species [2, 3].

Rats, in which PRL is the main luteotropic hormone, have been most extensively investigated with regard to the role of this hormone in ovarian function. On the other hand, information on the direct action of PRL on ovarian cell types in porcine is limited.

Our earlier in vitro studies on theca cells (Tc), granulosa cells $(\mathrm{Gc})$ and early corpus luteum cells (ECL) isolated from proestrus porcine ovary and cultured as monolayer showed that PRL significantly stimulated progesterone $\left(\mathrm{P}_{4}\right)$ secretion by cultures of Tc alone as well as by luteal cells of ECL. $\mathrm{P}_{4}$ secretion was also stimulated by co-cultures of Tc and Gc but not by $\mathrm{Gc}$ alone in monoculture $[4,5]$. 
Tc in the pig, contrary to human, rat and bovine, have certain aromatizing abilities. Basal estradiol $\left(E_{2}\right)$ secretion from Tc was higher than that from Gc $[6,7]$. Modulation of steroidogenesis in cultured luteal cells from ECL by PRL and its distinct luteotropic action shown in vitro were reported elsewhere $[2,5,8]$. PRL was also detected in porcine follicular fluid [9]. This luteotropic action of PRL was later confirmed in vivo by Ciereszko and Dusza [10]. They showed that exogenous PRL elevated plasma $\mathrm{P}_{4}$ concentrations during the early luteal phase of the porcine estrous cycle. In our cultures, we used medium supplemented with $5-10 \%$ calf serum, which contains low density lipoproteins (LDL). Rajkumar et al. [11, 12] and recently Ciereszko et al. [13] showed that PRL affected LDL processing in luteal tissue which resulted in enhanced $\mathrm{P}_{4}$ secretion by ECL cells.

PRL binding by luteal cells of pig was first observed by Rolland et al. [14] and PRL stimulation of Gc steroidogenesis was reported by Veldhuis et al. [15]. PRL receptors were localized in the ovary of hamster [16], rat [17, 18], mouse [19] and human [20].

Recently, PRL-R has been cloned and identified [21]. It belongs to the growth hormone/cytokine receptor superfamily. Two different forms of the receptor, short and long have been identified [22].

PRL-Rs have not been shown as yet to be present in porcine theca tissue. Its sensitivity to PRL expressed in terms of increased steroid secretion suggested that the PRL signal could be transduced via specific receptors.

The main rationale of this experiment was to show the presence of PRL-R in porcine theca interna tissue and in ECL and to see whether the observed stimulation of steroidogenesis in those cells could be caused by PRL binding to its receptor.

\section{Materials and Methods}

\section{Chemicals}

Highly purified ovine prolactin (28 i.u./mg) used in cell culture was obtained from NIH, Bethesda, MD, USA, while porcine PRL (30i.u./mg) obtained according to Kochman and Kochman [23] was used for the binding assay.
Medium M199, penicillin, trypsin and calf serum were products of the Laboratory of Sera and Vaccines, Lublin, Poland. Monoclonal (mouse) anti PRL-R antibody ( $\mathrm{IgG}_{1}$ )-clone U5 was purchased from Affinity Bioreagents (Golden, CO, USA). Biotinylated anti-mouse antibody (IgG) raised in horse was obtained from Vector (Burlingame, CA, USA). Strep-ABComplex-HRP was from Dako (Glostrup, Denmark). Bio-Rad protein assay reagent was purchased from BioRad Laboratories (Richmond, CA, USA). Isotopes for RIA were obtained from Amersham (Little Chalfont, England), anti-progesterone antibody was a generous gift from Professor B. Cook, University of Glasgow, (Glasgow, Scotland) and anti-estradiol antibody was a gift from Professor R. Rembiesa (Institute of Pharmacology, Polish Academy of Sciences, Kraków, Poland). $1 \mathrm{mCi}\left[{ }^{125} \mathrm{I}\right]$ was obtained from Amersham (Little Chalfont, England).

\section{Tissue}

Porcine ovaries were obtained from slaughterhouse animals and classified according to Akins and Morrissette [24] and Channing and Ledwitz-Rigby [25]. Large proestrous follicles $0.9-1.2 \mathrm{~cm}$ diam. and ECL were selected for culture. For immunohistochemical and binding studies small, medium, and large follicles $(3-4 \mathrm{~mm}, 5-8 \mathrm{~mm}$, and $8-12 \mathrm{~mm}$ diam., respectively) and fragments of ECL were excised from porcine ovaries.

\section{Cell culture}

Tc were isolated using our own technique [26]. ECL, containing blood clot in the center, were removed from postovulatory ovaries (1-3 days after ovulation) and then dispersed enzymatically according to Gregoraszczuk [2]. Thecal and luteal cells were suspended in Medium M199 supplemented with $5 \%$ calf serum at densities of $3.5 \times 10^{5}$ and $5 \times 10^{5}$ cells per $1 \mathrm{ml}$ medium, respectively. Cells were grown in multiwell plates (Nunc, Roskilde, Denmark) in a humidified atmosphere of $5 \% \mathrm{CO}_{2}$ in air for $48 \mathrm{hrs}$. In order to select the most effective dose of PRL, a dose response curve from 0 to 10,100 and $500 \mathrm{ng}$ of PRL was prepared in an earlier experiment [8]. The optimal dose of $100 \mathrm{ng}$ PRL was used in the present experiments. Cells were cultured in the 
control medium without PRL or in medium supplemented with $100 \mathrm{ng}$ PRL per $1 \mathrm{ml}$. In addition, cells were also cultured in medium containing $100 \mathrm{ng} \mathrm{LH}$ per $1 \mathrm{ml}$. The latter was introduced as an additional control since it is well known that Tc contain LH receptor, the hormone which is luteotropic in pig. The dose of $100 \mathrm{ng} \mathrm{LH}$ is long known as the most effective one in cell culture experiments [2].

\section{Steroid hormone measurement}

The amount of $\mathrm{P}_{4}$ secreted to medium was determined by radioimmunoassay according to Abraham et al. [27]. A highly specific antibody raised in rabbit against $11 \alpha$-progesterone hemisuccinate coupled to bovine serum albumin was used. The cross-reaction with prognenolone was $2.9 \%$. The other steroids tested showed a cross-reactivity below $1 \%$. [1,2,6,7${ }^{3} \mathrm{H}$ ] progesterone was used as the tracer $(80 \mathrm{Ci}$ $/ \mathrm{mmol})$. The detection limit of the assay was $50 \mathrm{pg}$ $/ \mathrm{ml}$. The coefficients of variation within and between assays were below $1.5 \%$ and $2.5 \%$ respectively.

Estradiol-17 $\beta\left(\mathrm{E}_{2}\right)$ was analysed by the radioimmunoassay according to Hotchkis et al. [28]. A highly specific antibody raised in rabbit against $17 \beta$ 6-oxime-BSA antigen was used. It gave negligible cross-reaction with estrone $(0.8 \%)$, estriol $(0.8 \%)$ and 16-keto-estradiol $17 \beta(1 \%)$. [2,4,6,7,16,17- $\left.{ }^{3} \mathrm{H}\right]-$ Estradiol was used as the tracer $(140 \mathrm{Ci} / \mathrm{mmol})$. The detection limit of the assay was $5 \mathrm{pg}$. The data were expressed as nanograms of steroids secreted into $1 \mathrm{ml}$ of medium per $1 \times 10^{5}$ cells for $48 \mathrm{~h}$ of culture. All data were expressed as means \pm SEM derived from at least three different experiments $(n=3)$, each in quadruplicates, which means at least twelve observations. The differences between steroid concentrations in control and treated cultures were evaluated by ANOVA test.

\section{Immunohistochemical procedures}

Isolated porcine ovarian follicles of different sizes (small, medium, large) as well as early corpora lutea, were fixed in buffered $4 \%$ formalin for $24 \mathrm{~h}$, dehydrated in a series of increasing gradient of ethanol and embedded in paraffin. Sections were cut at $6 \mu \mathrm{m}$, mounted on silanised glass slides, dewaxed in xylene, hydrated in ethanol (decreasing gradient) and washed in PBS. To retrieve antigenicity, slides were placed in a plastic box with $0.01 \mathrm{M}$ citrate buffer, pH 6.0 and heated in a $750 \mathrm{~W}$ microwave 3 times for 5 min. Between each cycle, the evaporated buffer was supplemented with hot distilled water. After cooling, the slides were incubated with $0.3 \% \mathrm{H}_{2} \mathrm{O}_{2}$ in PBS, to quench endogenous peroxidase activity and then with $3 \%$ normal horse serum to block nonspecific binding. Finally, slides were incubated with monoclonal anti-PRL-R antibody (at dilution $1: 40$ ) overnight at $4^{\circ} \mathrm{C}$. Sections were washed in 3 changes of Tris-buffered saline with $0.1 \%$ Tween 20, pH 7.6 (TBST), then incubated with biotinylated horse antimouse IgG for $1.5 \mathrm{~h}$ at room temperature, washed again with TBST and incubated with Strep-ABComplex-HRP. Colour reaction was developed in Trisbuffered saline $\mathrm{pH} 7.6$ (TBS) containing diaminobenzidine $(50 \mathrm{mg} / 100 \mathrm{mlz}), 0.01 \mathrm{M}$ imidazole and $0.3 \% \mathrm{H}_{2} \mathrm{O}_{2}$. For negative control, the primary antibody was omitted.

\section{PRL binding assay}

Porcine PRL $(2.5 \mu \mathrm{g})$ was labelled with $1 \mathrm{mCi}$ [ $\left.{ }^{125} \mathrm{I}\right]$ by a modified method of Greenwood et al. [29] using $2 \mu \mathrm{g}$ chloramine $\mathrm{T}(1 \mu \mathrm{g}$ added at the beginning of the reaction, and $1 \mu \mathrm{g}$ added after $2 \mathrm{~min}$.). Reaction was stopped after $4 \mathrm{~min}$. Unreacted $\left[{ }^{125} \mathrm{I}\right]$ was separated by gel filtration on a column of Sephadex G-50. The labelled porcine PRL was further purified on a Sephadex G-100 column equilibrated with $0.01 \mathrm{M}$ PBS buffer, pH 7.5, containing 0.1\% BSA. Labelled PRL was used at 50,000-200,000 cpm per tube.

Theca interna tissue from small, medium and large follicles was carefully separated from Gc and fragments of ECL were excised on ice and then frozen in $-70^{\circ} \mathrm{C}$ until assay.

Homogenization of tissue was performed in incubation buffer $25 \mathrm{mM}$ Tris- $\mathrm{HCl}, \mathrm{pH} 7.4,10 \mathrm{mM}$ $\mathrm{MgCl}_{2}, 0.1 \%$ BSA. Homogenates obtained from $2 \mathrm{mg}$ of tissue (which is equivalent to $100 \mu \mathrm{g}$ protein) were incubated with [ $\left.{ }^{125} \mathrm{I}\right] \mathrm{PRL}$ (porcine) in a total volume of $0.4 \mathrm{ml}$. Protein concentration of the homogenate was measured by Bradford method using Bio-Rad protein assay reagent [30].

Incubation was carried out at $23^{\circ} \mathrm{C}$ for 12 hours. Incubation suspension was then applied to glass microfiber filters GF/A (Whatman, Clifton, NJ, USA) presoaked in $2 \%$ bovine serum albumin, retained in a multiplace holder, and was filtered to 
separate bound [125I] PRL from free ligand. Filters were washed 5 times with $2 \mathrm{ml}$ of cold incubation buffer. Radioactivity of the dried pellet was counted in a $\gamma$-counter [31]. Specific binding was defined as the difference between total and nonspecific (in the presence of excess of unlabeled porcine PRL, $2 \mu \mathrm{g}$ ) binding. Scatchard analysis was performed as it described elsewhere [32].

\section{Results}

\section{Steroid secretion}

Theca cells in control cultures secreted small amounts of $\mathrm{P}_{4}\left(0.47 \pm 0.02 \mathrm{ng} / 10^{5}\right.$ cells $)$; LH stimulated $\mathrm{P}_{4}$ production up to $1.2 \pm 0.05 \mathrm{ng} / 10^{5}$ cells $(\mathrm{p} .<$ $0.01 ; 2.5$-fold). The most significant stimulation, almost 10-fold, was observed under the influence of PRL (4.25 $\pm 0.5 \mathrm{ng} / 10^{5}$ cells, $\left.\mathrm{p}<0.001\right)$ (Fig. 1).

ECL cells secreted a much higher amount of $P_{4}$, $1171 \pm 12 \mathrm{ng} / 10^{5}$ cells in control cultures, while LH stimulated secretion of this steroid up to $1390 \pm 20$ $\mathrm{ng} / 10^{5}$ cells $(\mathrm{p}<0.01 ; 1.1$-fold $)$. In the presence of $\mathrm{PRL}$, the increase of $\mathrm{P}_{4}$ secretion was twofold vs control $\left(2028 \pm 40 \mathrm{ng} / 10^{5}\right.$ cells, $\left.\mathrm{p}<0.001\right)$ (Fig. 1).

The $E_{2}$ secretion from $T c$ control cultures was $0.58 \pm 0.02 \mathrm{ng} / 10^{5}$. LH stimulated markedly $E_{2}$ secretion from Tc cultures up to $1.58 \pm 0.04 \mathrm{ng}$ ( $p<$
0.001). PRL stimulated $E_{2}$ secretion almost as strongly as LH only by cultures of theca $(1.42 \pm 0.06$ $\mathrm{ng} / 10^{5}$ cells, $\mathrm{p}<0.001$ ) (Fig. 2).

$E_{2}$ secretion from luteal cells of ECL was not stimulated; on the contrary, it was significantly suppressed by either hormone used (Fig. 2).

\section{Immunohistochemical localization of $P R L-R$}

Analysis of cross-sections of whole ovarian follicles demonstrated PRL-R immunoreactivity in Gc, Tc and in ECL cells. Follicles of different sizes showed similar pattern of immunoreactivity. Immunostaining was localized on the cell membrane and in the cytoplasm. No nuclear staining was observed. Some but not all cells, showed PRL-R immunoreactivity.

In small antral follicles PRL-R was localized mainly in cells of granulosa layer, particularly in the upper part of the mural area (Fig. 3A). Negative reaction was observed in $\mathrm{Tc}$. In medium and large follicles PRL-R was seen in Tc (Fig. 3B, 3C), but it expressed a much weaker reaction than that observed in Gc. In ECL cells as well as in Tc of both medium and large follicles, immunostaining for PRL-R was clearly visible (Fig. 3D).

In the control, omission of the primary antibody resulted in a lack of staining.

\section{Theca cells}

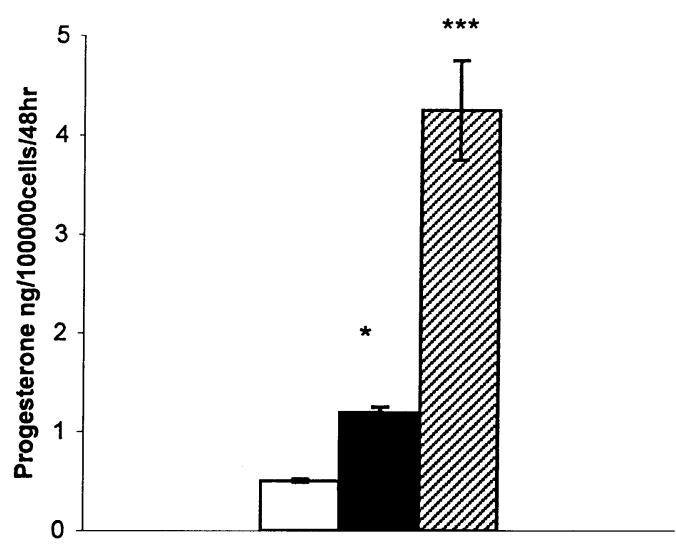

Corpus luteum

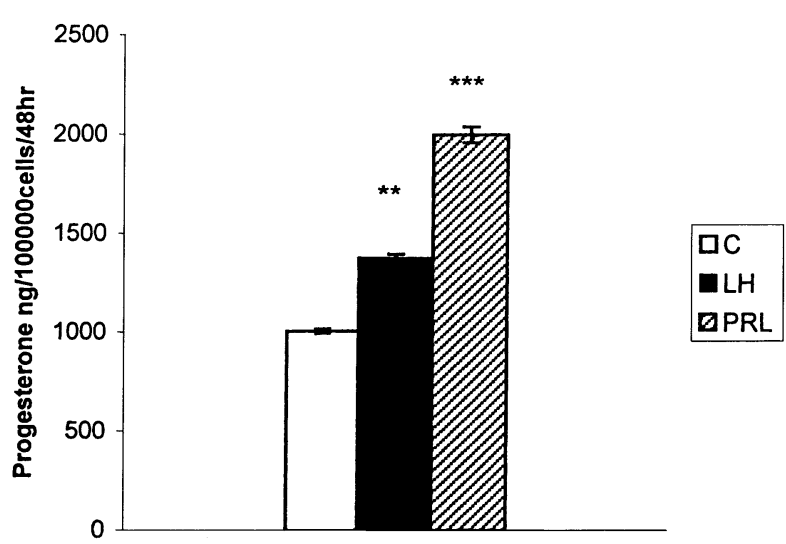

Fig. 1. Progesterone secretion (ng per $1 \times 10^{5}$ cells) from theca cells and early corpus luteum cells under the influence of LH $(100 \mathrm{ng} / \mathrm{ml})$ and PRL $(100 \mathrm{ng} / \mathrm{ml})$ during $48 \mathrm{hr}$ culture. Each bar represents the mean \pm SEM of 12 observations from 3 independent experiments $(\mathrm{n}=3)$. ${ }^{*} \mathrm{p}<0.05 ;{ }^{* *} \mathrm{p}<0.01 ;{ }^{* * *} \mathrm{p}<0.001$. The differences between progesterone concentrations in control and treated cultures were evaluated by ANOVA test. 
Theca cells

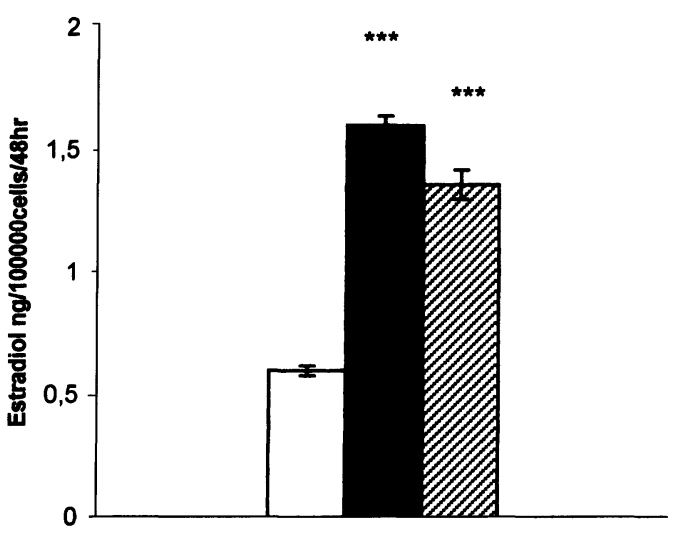

Corpus luteum

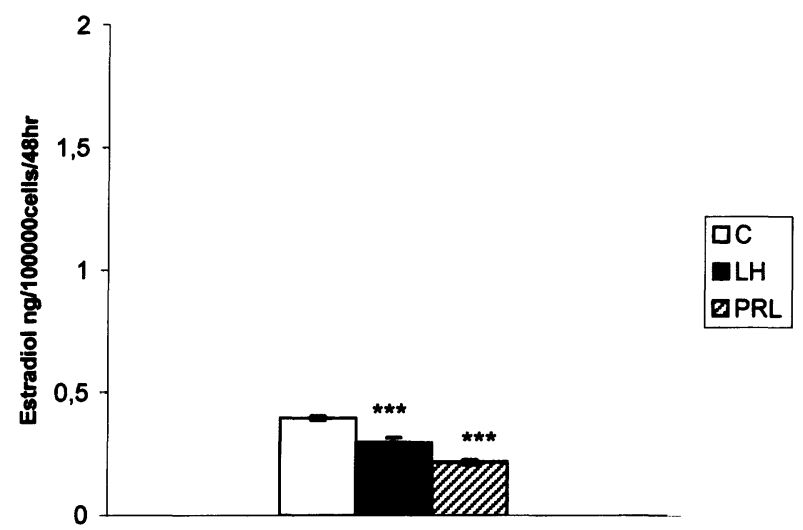

Fig. 2. The effect of $\mathrm{LH}(100 \mathrm{ng} / \mathrm{ml})$ and PRL $(100 \mathrm{ng} / \mathrm{ml})$ on estradiol- $17 \beta$ secretion $\left(\mathrm{ng}\right.$ per $1 \times 10^{5}$ cells) from theca cells and early corpora lutea cells during $48 \mathrm{hr}$ culture. Each bar represents the mean \pm SEM of 12 observations from 3 independent experiments $(\mathrm{n}=3) .{ }^{*} \mathrm{p}<0.05 ;{ }^{* *} \mathrm{p}<0.01 ;{ }^{* * *} \mathrm{p}<0.001$. The differences between estradiol concentrations in control and treated cultures were evaluated by ANOVA test.

\section{Identification of PRL-R by binding assays}

The amount of PRL-R protein $\left(\mathrm{B}_{\max }\right)$ in Tc of small, medium and large follicles and in ECL tissue was calculated by Scatchard plot (Fig. 4A, 4B, 4C), and results are summarised in Table 1 . In accordance with the result of immunohistochemical analysis (Fig. 3A), PRL binding was negative in Tc of small antral follicles. First appearance of PRL binding was seen in Tc of medium follicles $\left(\mathrm{B}_{\max }\right.$ $=0.97 \pm 0.052, \mathrm{n}=5)$, in Tc of large follicle $(1.573$ $\pm 0.45, \mathrm{n}=7)$ and in ECL cells $(1.7 \pm 0.14, \mathrm{~N}=8)$ which contained the largest number of PRL-R.

\section{Discussion}

PRL binding to ovaries was reported in rat [17, 33], hamster [16] mouse [19] and human [20]. Magoffin and Erickson [18, 34] demonstrated specific high affinity PRL-Rs in cultured interstitial cells of the rat ovary. On the other hand, data on PRL binding to porcine ovaries are scarce. Rolland and Hammond [35] first showed PRL binding to pig ovaries and Veldhuis et al. $[15,36]$ detected PRL binding to cultured $\mathrm{Gc}$ and indicated its dependency on cytodifferentiation.

No information is available on PRL binding with pig follicular theca interna cells as well as by cells of
ECL in which, during a short postovulatory phase of its formation, the thecal component is quite substantial [37]. In the present study, cultured porcine Tc exhibited distinct sensitivity to exogenous PRL as measured by $\mathrm{P}_{4}$ and $\mathrm{E}_{2}$ secretion to culture medium $[4,5]$. The amount of secreted steroids was comparable to that secreted in response to LH (Fig. 1). It is well known that $\mathrm{Tc}$ are equipped with $\mathrm{LH}$ receptors that are involved in stimulation of $\mathrm{P}_{4}$ and androgen synthesis in majority of mammalian species. However, porcine Tc, unlike Tc of the other species, have certain aromatizing ability. In culture, they secreted significant amount of $E_{2}$, which was markedly stimulated by testosterone [6,7]. Results of the present experiment showed that PRL acts directly on Tc and ECL cells. The recent publication by Ciereszko et al. [13] showed that PRL action on ovarian cells is mediated by LDL. These lipoproteins were apparently present in the serum supplement of the medium in which cells in this experiment were grown. However, this finding and earlier reports by Rajkumar et al. [11,12] do not exclude the role of PRL-R in the mechanism underlying Tc and ECL functions in the porcine ovary. The present preliminary study using Scatchard analysis revealed for the first time in the pig, femtomol levels of PRL-R protein in Tc of medium and large follicles. PRL-R was also detected in ECL tissue (Table 1). These results were strengthened by results of im- 

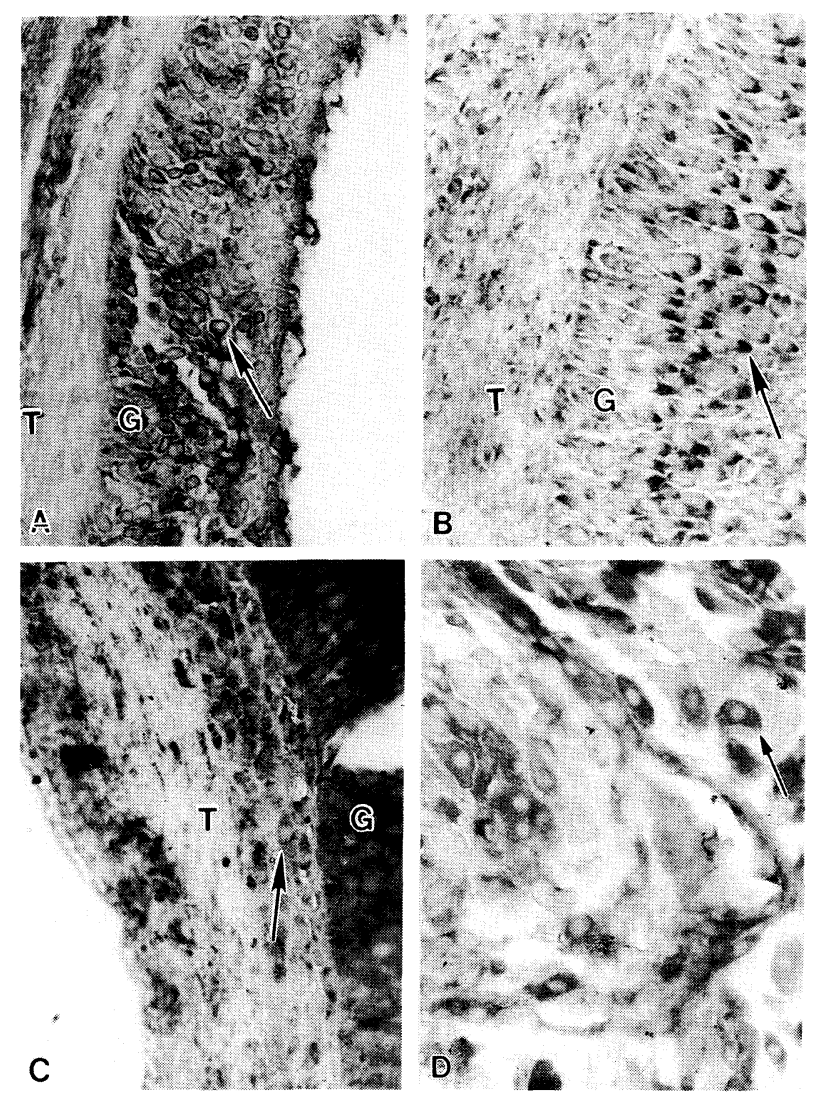

Fig. 3. Immunohistochemical localization of prolactin receptor in the porcine follicles and corpus luteum. A. small antral follicle, with PRL-R present in granulosa layer (arrow); B. medium follicle, with PRL-R localized in both granulosa cells (arrow) and theca layer; C. large follicle, with immunopositive staining in granulosa and theca (arrow); D. early corpus luteum, with prolactin receptor present in several cells (arrow). Magnification $\times 200$.

munohistochemical detection of PRL-R in porcine ovary. Similarly as in the quantitative assay, Tc of small antral follicles was not immunopositive (Fig. 3A). As there are some immunogenic domains of the receptor conserved between species, antibody to the rat liver PRL-R, U5, could be used in the experiments carried on the porcine ovary [38]. Antibody U5 is very useful in characterization of the structure of the PRL-R in various stages of receptor processing. In partially purified receptors from pig mammary gland, in the immunoblot analysis, bands of 66,000 and $36,000 \mathrm{~mol}$ wt were seen [38]. Using slices of ECL tissue it was difficult to discriminate which cell type was the bearer of PRL-R. Grego- raszczuk [8, 39], and Gregoraszczuk and Krzysztofowicz [40] showed that the large luteal cells of ECL responded to PRL action by increase in $\mathrm{P}_{4}$ secretion. These results allowed us to assume that large luteal cells are equipped with PRL-R. PRL binding experiments should be performed in the future using separated luteal cell types. Taking into consideration, significant increase in steroidogenesis in cultured Tc and luteal cells, one would predict the presence of higher receptor number. However, the possibility can not be excluded, that PRL-R, similar to receptors for the other gonadotropins and those of steroid hormones, undergo a time dependent dynamics of up- and down-regulations, which are rather difficult to target during the much longer pig estrous cycle [41-43] than rat estrous cycle. PRL-R gene expression was visualized in various tissues by in situ hybridization. The levels and localization of PRL-R mRNA in the rat ovary changes throughout the reproductive cycle. In the rat $\mathrm{Tc}$ the short form was present during early proestrus, while in diestrus the long form of PRL-R mRNA appeared to be expressed in the Tc region [44]. On the contrary, using the same technique, no differences in the abundance of PRL-R mRNA were observed between follicles of different sizes, healthy vs. atretic or stage of the estrous cycle or pregnancy, as well as between CL from pregnant and nonpregnant deer [45]. In all follicles, PRL-R mRNA was localized to the Tc layer. These results suggest a direct role of PRL in red deer ovarian physiology [45]. However this animal is not a proper sample, because it is a seasonal, short day breeder. The timing of hormonal events is incomparable with animals dependent on long day breeding.

Apart from receptor mediated action, the likelihood of an additional paracrine mechanism of PRL action within porcine ovary was suggested by Einspanier [46]. The author found detectable concentrations of PRL mRNA in pig Gc and luteal cells, and also described the capacity of these cells to produce PRL. Gonadotropins may act on ovarian cells before they develop appropriate receptors [47]. According to the authors [47], FSH affected ovarian androgen synthesis via a paracrine fashion involving increased expression of rat Tc P450-17 $\alpha$ enzyme. Since Tc do not express FSH receptors, the authors suggested involvement of some paracrine proteins (possibly inhibin or IGF-I) produced by Gc in 

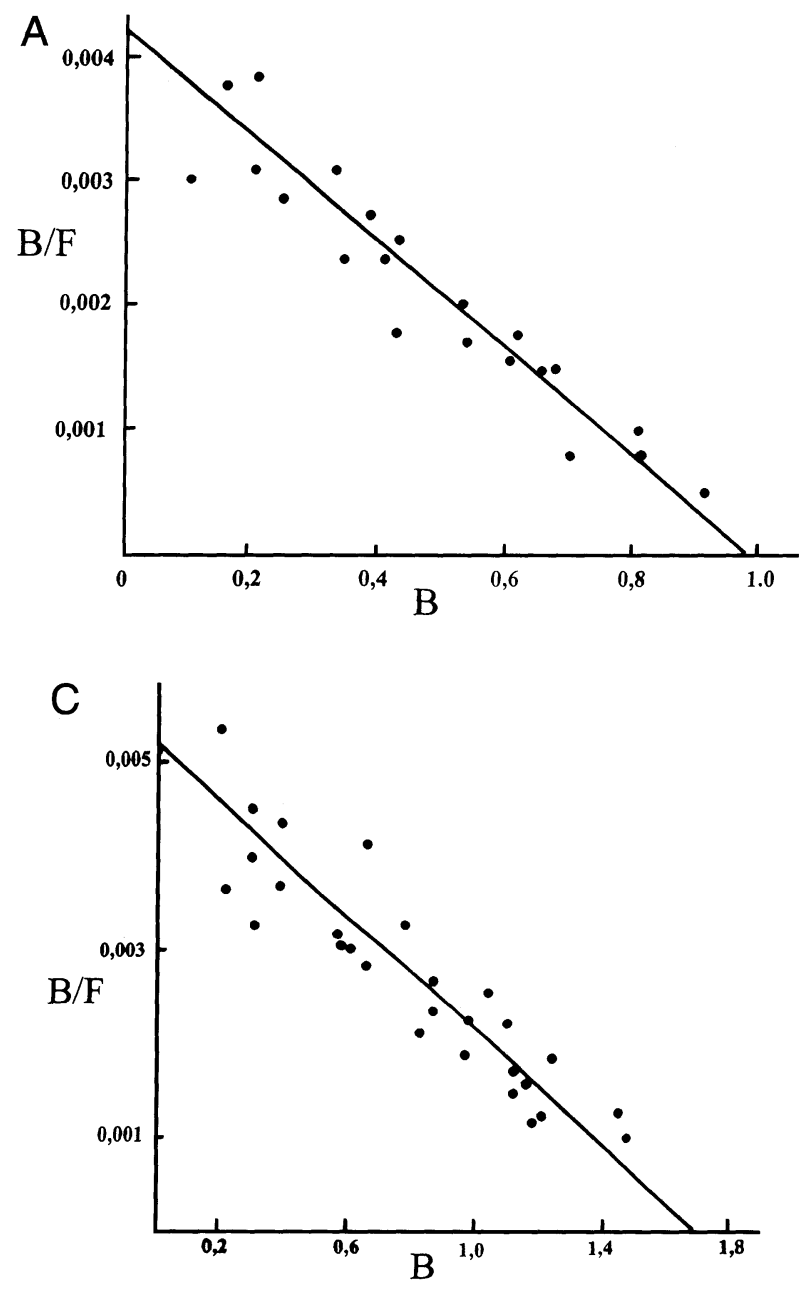

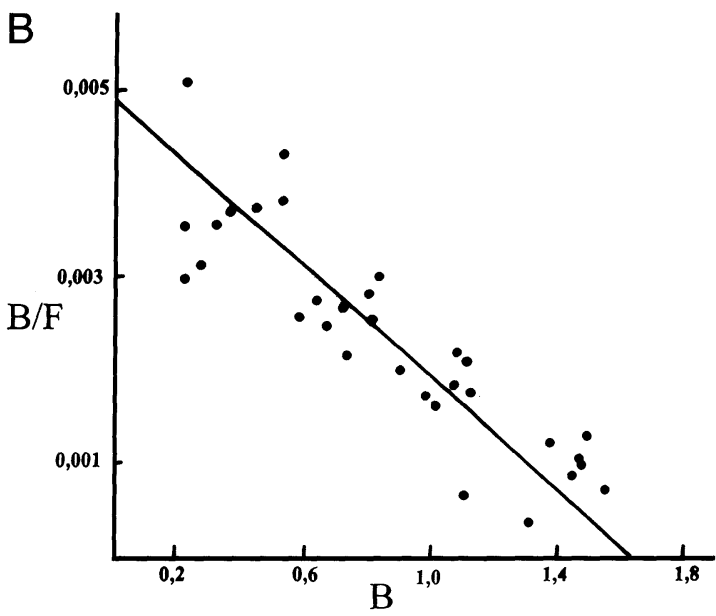

Fig. 4. Composite Scatchard plots of [125I] PRL binding with theca cells of medium and large follicles as well as early corpus luteum. Five, eight and seven respective binding assays were performed for the tissue types investigated. Raw data were retrieved and a straight line representing composite results for each tissue type was provided to determine binding parameters $\left(B_{\max }, K_{a}, K_{d}\right)$. Scatchard plots were made for: $\mathrm{A}$. theca from medium follicles; $\mathrm{B}$. theca from large preovulatory follicles; $C$. early corpus luteum.

In theca of small follicles PRL-R protein was undetectable as estimated by binding assay. $\mathrm{B}_{\max }$ represents the amount of PRL-R binding sites per $100 \mu \mathrm{g}$ of protein (fmol/100 $\mu \mathrm{g}$ protein)

Table 1. Summary of PRL-R binding assay in theca cells (Tc) of small, medium and large follicles as well as in early corpus luteum cells (ECL).

\begin{tabular}{lllll}
\hline Cell type & $\mathrm{B} / \mathrm{F}_{(0)}$ & $\mathrm{B}_{\max }$ & $\mathrm{K}_{\mathrm{a}}$ & $\mathrm{K}_{\mathrm{d}}$ \\
Tc-small follicle & $\mathrm{ND}$ & $\mathrm{ND}$ & $\mathrm{ND}$ & $\mathrm{ND}$ \\
Tc-medium follicle & $0.00419 \pm 0.00027$ & $0.97 \pm 0.052$ & $2.15 \pm 0.22 \times 10^{12} \mathrm{M} .^{-1}$ & $4.46 \pm 0.56 \times 10^{-13} \mathrm{M}$ \\
Tc-large follicle & $0.004985 \pm 0.000646$ & $0.573 \pm 0.45$ & $1.489 \pm 0.29 \times 10^{12} \mathrm{M}^{-1}$ & $6.97 \pm 1.32 \times 10^{-13} \mathrm{M}$ \\
ECL & $0.0052 \pm 0.00063$ & $1.7 \pm 0.14$ & $1.53 \pm 0.23 \times 10^{12} \mathrm{M}^{-1}$ & $6.54 \pm 1.29 \times 10^{-13} \mathrm{M}$ \\
\hline
\end{tabular}

Data are presented as mean $\pm S D$; Tc small follicle $(n=5)$; Tc medium follicle $(n=5)$; Tc large follicle $(n=8)$; ECL $(\mathrm{n}=7)$.

$\mathrm{B} / \mathrm{F}$, ligand ratio while binding is $0 ; \mathrm{B}_{\max }$, maximum binding (fmol/100 $\mu \mathrm{g}$ protein); $\mathrm{K}_{\mathrm{a}}$, affinity constance; $\mathrm{K}_{\mathrm{d}}$, dissociation constance, ND, undetectable

response to FSH. Magoffin and Magarelli [48] and Magarelli et al. [49] demonstrated that developing preantral follicles secrete paracrine substances, proteinaceous in nature, possesing androgen stimulating activity. These, termed theca differentiating factors
(TDF), might be involved in initiating a genetic program resulting in an expression of $\mathrm{LH}$ receptor and steroidogenic enzymes specific for Tc. This interesting interpretation indicates an indirect way by which FSH may stimulate not only aromatase activity in Tc 
but also androgen substrate production.

Recently, the role of testicular macrophages in stimulating steroidogenesis of Leydig cells (LC) was suggested by Hutson [50]. It appeared that macrophages residing in the testis are equipped with FSH receptors. The digitations connecting neighbouring LC and macrophages were observed. The author postulated that FSH bound with macrophages but not with LC, which is lacking in FSH receptor, stimulates synthesis and secretion of various peptides and cytokines which in a paracrine way may enhance steroidogenesis in LC. It has been shown that macrophages reside in pig ovaries [51, 52] and their number varies in different stages of estrous cycle. Gc in coculture with macrophages secreted more $\mathrm{P}_{4}$ than cultured alone [53]. Interestingly, Standaert et al. [51] found that conditioned medium from splenocytes as well as monocytes and lymphocytes influenced steroid secretion by pig granulosa cells. Similarly, in co-cultures splenic macrophages enhanced stimulatory action of PRL on $\mathrm{P}_{4}$ secretion by Gc [54]. Considering homology between testicular and ovarian cells, it is reasonable to suggest that ovarian macrophages could also bear receptors of FSH and its binding could trigger a paracrine mechanism in cells which are not the direct target for this hormone. In this experiment immunostained slices of Tc revealed that not all $\mathrm{Tc}$ showed positive staining for
PRL-R. However, this preparation made it impossible to prove whether PRL-R antibody was bound with Tc or to macrophages or to another cell type present in this complex tissue. On the basis of the concepts presented above, one may speculate that in addition to the classical signal transduction via adequate membrane receptors, PRL could also act on Tc by a similar but as yet unknown mechanism. This interesting idea should be clarified in further investigations using separated ovarian cell types.

In conclusion $\mathrm{Tc}$ of porcine medium and large follicles as well as ECL respond to PRL in terms of increased steroid secretion. This action is mediated by PRL-R as detected in both tissues by binding assay and immunohistochemical technique.

\section{Acknowledgements}

This work was supported by Grant KBN No6PO4C 11208, by WHO SMA Grant, Special Program of Research, Development and Research Training in Human Reproduction and partially by DS/IZ/ZF/20/97 grant. The authors are grateful to M. Duda MSc for steroid analysis, H. Kochman MSc for performing Scatchard analysis and to M. Fijak MSc for technical assistance.

\section{References}

1. Watson CJ, Burden TG (1996) Prolactin signal transduction mechanisms in the mammary gland: the role of Jak/Stat pathway. Reviews of Reprod 1: 1-5.

2. Gregoraszczuk E (1983) Steroid hormone release in cultures of pig corpus luteum and granulosa cells: Effect of LH, hCG, PRL and estradiol. Endocrinol Experiment 17: 59-68.

3. Dusza L, Tilton JE (1990) Role of prolactin in the regulation of ovarian function in pigs. $J$ Reprod Fert, Suppl 40: 33-45.

4. Stokłosowa S, Gregoraszczuk E (1981) Do theca interna cells contribute to corpus luteum formation?: Tissue culture approach. Cell Biology Intl Reports 5: 770-771.

5. Stokłosowa S, Gregoraszczuk E (1996) The involvement of prolactin in steroidogenesis. Gin Pol 67, Sup 6: 21-28.

6. Haney AF, Schomberg DW (1981) Estrogen and progesterone production by developing porcine folli- cles in vitro: Evidence for estrogen formation by theca cells. Endocrinology 109: 971-977.

7. Stoklosowa S, Gregoraszczuk E, Channing CP (1982) Estrogen and progesterone secretion by isolated cultured porcine thecal and granulosa cells. Biol Reprod 26: 943-952.

8. Gregoraszczuk E (1990) Different response of porcine large and small luteal cells to PRL in terms of progesterone and estradiol secretion in vitro. Exp Clin Endocrinol 96: 234-237.

9. Przała J, Grażul A, Więsak T, Muszyńska A, Dusza L (1984) Steroid hormones and prolactin in porcine follicular fluid in estrous cycle and early pregnancy. Exp Clin Endocrinol 85: 101-110.

10. Ciereszko R, Dusza L (1993) Exogenous prolactin elevates plasma progesterone concentrations and reduces androgen concentrations during early luteal phase of the porcine estrous cycle. Animal Reprod Sci 31: 141-154. 
11. Rajkumar K, Coulture RL, Murphy BD (1985) Binding of high-density lipoproteins to luteal membranes: The role of prolactin, luteinizing hormone and circulating lipoproteins. Biol Reprod 32: 546-555.

12. Rajkumar K, Malinek J, Murphy BD (1985) Effect of lipoproteins and luteotrophins on progesterone accumulation by luteal cells from the pregnant pig. Steroids 45: 119-134.

13. Ciereszko RE, Petroff BK, Ottobre AC, Guan Z, Stokes BT, Ottobre JS (1998) Assessment of the mechanism by which prolactin stimulates progesterone production by early corpora lutea of pigs. $J$ Endocrinol 159: 201-209.

14. Rolland R, Gunslaus, GL, Hammond JM (1976) Demonstration of specific binding of prolactin by porcine corpora lutea. Endocrinology 98: 1083-1091.

15. Veldhuis JK, Klase PA, Hammond JM (1981) Sex steroids modulate prolactin action in spontaneously luteinizing porcine granulosa cells in vitro. Endocrinology 108: 1463-1468.

16. Oxberry BA, Greenwald GS (1982) Autoradiographic analysis of proestrous changes in the binding of ${ }^{125} \mathrm{I}-$ labelled prolactin to hamster ovary. Biol Reprod 29: 1255-1263.

17. Midgley Jr. AR (1973) Autoradiographic analysis of gonadotropin binding to rat ovarian tissue sections. Adv Exp Med Biol 36: 365-373.

18. Magoffin DA, Erickson GF (1982) Prolactin inhibition of luteinizing hormone-stimulated androgen synthesis in ovarian interstitial cells cultured in defined medium: mechanisms of action. Endocrinology 111: 2001-2007.

19. Brown-Borg H.M, Zhang F-P, Huhtaniemi I, Bartke A (1996) Developmental aspects of prolactin receptor gene expression in fetal and neonatal life. Eur J Endocrinol 134: 751-757.

20. Poindexter AN, Buttram VC Jr, Besch P, Smith RG (1979) Prolactin receptors in the ovary. Fert Steril 31: 273-279.

21. Kelly PA, Djiane J, Postel-Vinay M.-C, Edery M (1991) The prolactin/growth hormone receptor family. Endocrine $\operatorname{Rev} 12:$ 235-251.

22. Kelly PA, Ali S, Rozakis M, Goujon L, Nagano M, Pellegrini I, Gould D, Djiane J, Postel-Vinay MC, Edery M (1993) The prolactin/growth hormone receptor family. Rec Progr Hormone Res 48: 123-164.

23. Kochman H, Kochman K (1977) Purification of ovine and bovine prolactins on DEAE cellulose chromatography and preparative polyacrylamide gel electrophoresis. Bull Acad Sci Pol 2: 67-75.

24. Akins EL, Morrissette MC (1968) Gross ovarian changes during estrous cycle of swine. Am J Vet Res 29: 1953-1957.

25. Channing CP, Ledwitz-Rigby F (1975) Methods for assessing hormone mediated differentiation of ovarian cells in culture and short-term incubations. In: Hardman JG and O'Malley BW (eds) Academic Press, New York. Methods in Enzymology, vol. 39: 183-230.

26. Stoklosowa S, Bahr J, Gregoraszczuk E (1978) Some morphological and functional characteristics of cells of porcine theca interna in tissue culture. Biol Reprod 19: 712-719.

27. Abraham GE, Swerdloff R, Tulchinsky D, Odell WS (1971) Radioimmunoassay of plasma progesterone. $J$ Clin Endocrinol 32: 619-624.

28. Hotchkis J, Atkinson LE, Knobil E (1971) Time course of serum estrogen and luteinizing hormone (LH) concentration during the menstrual cycle of the rhesus monkey. Endocrinology 89: 177-183.

29. Greenwood FC, Hunter WM, Glover JS (1963) The preparation of I-labelled human growth hormone of high specific radioactivity. J Biochem 89: 114-123.

30. Bradford MM (1976) A rapid and sensitive method for the quantitation of microgram quantities of protein utilizing the of principle of protein-dye binding. Anal Biochem 72: 248-254.

31. Kochman H, Garnier J, Kochman K (1979) Receptor binding and conformational properties of bovine and ovine prolactins after chemical modification of the two tryptophan residues. $B B A$ 578: 125-134.

32. Scatchard G (1949) The attraction of proteins for small molecules and ions. Ann NY Academy Sci 51: 660-668.

33. Dunaif AE, Zimmerman EA, Friesen HG, Frantz AG (1982) Intracellular localization of prolactin receptor and prolactin in rat ovary by immunohistochemistry. Endocrinology 110: 1464-1471.

34. Magoffin DA, Erickson GF (1994) Control systems of theca-interstitial cells. In: Findlay JK (eds) Cellular and molecular mechanisms of female reproduction. Academic Press, Orlando, FL: 39-65.

35. Rolland R, Hammond JM (1975) Demonstration of specific receptor for prolactin in porcine granulosa cells. Endocrine Res Comm 2: 281-298.

36. Veldhuis JD, Klase P, Hammond JM (1980) Divergent effects of prolactin upon steroidogenesis by porcine granulosa cells in vitro: Influence of cytodifferentiation. Endocrinology 107: 42-46.

37. Gregoraszczuk E, Wojtusiak A (1982) Histochemical evaluation of $\Delta^{5}, 3 \beta$-OHD activity in two types of porcine corpora lutea and granulosa cells in tissue culture. Acta Histochem 70: 22-30.

38. Okamura H, Zachwieja J, Raguet S, Kelly PA (1989) Characterization and applications of monoclonal antibodies to the prolactin receptor. Endorinology 124: 2499-2508.

39. Gregoraszczuk EL (1997) Progesterone, androgen and estradiol production by porcine luteal cell subpopulations: dependence on cell composition and periods of 
luteal phase. Endocrine Reg 31: 41-46.

40. Gregoraszczuk E, Krzysztofowicz E (1989) The corpus luteum of the pig. Scanning electron microscopic study of surface features at different times of incubation. Acta Biol Hung 40: 145-156.

41. Stokłosowa S, Szołtys M (1978) Hormonal dynamics in the preovulatory ovarian follicle and the oocyte in rat during proestrus. Ann Biol Anim Bioch Biophys 18: 503-509.

42. Szołtys M (1981) Oestrogens and progestagens in rat ovarian follicles during the oestrous cycle. $J$ Reprod Fertil 63: 221-224.

43. Gębarowska D, Zięcik AJ, Gregoraszczuk EL (1997) Luteinizing hormone receptors on granulosa cells from preovulatory follicles and luteal cells throughout the oestrus cycle of pigs. Animal Reprod Sci 49: 191205.

44. Clarke DL, Arey BJ, Linzer DI (1993) Prolactin receptor messenger ribonucleic acid expression in the ovary during the rat estrous cycle. Endocrinology 133: 2594-2603.

45. Clarke LA, Wathes DC, Jabbour HN, (1997) Expression and localization of prolactin receptor messenger ribonucleic acid in red deer ovary during the estrous cycle and pregnancy. Biol Reprod 57: 865-872.

46. Einspanier R, Pitzel L, Wuttke W, Hagendorff G, Preuss KD, Kardalinon E, Scheit KH (1986) Demonstration of mRNAs for oxytocin for and prolactin in porcine granulosa and luteal cells. Effect of these hormones on progesterone secretion in vitro. FEBS Letters 204: 37-40.
47. Hillier SG, Whitelaw PF, Smyth CD (1994) Follicular estrogen synthesis: the two-cell, two-gonadotropin' model revisited. Mol Cell Endocrinol 100: 51-54.

48. Magoffin DA, Magarelli PC (1995) Preantral follicles stimulate luteinizing hormone independent differentiation of ovarian theca-interstitial cells by an intrafollicular paracrine mechanism. Endocrine 3: 107112.

49. Magarelli PC, Zachow RJ, Magoffin DA (1996) Developmental and hormonal regulation of rat theca-cell differentiation factor secretion in ovarian follicles, Biol Reprod 55, 416-420.

50. Hutson JC (1994) Testicular macrophages. Intl Rev Cytology 149: 99-143.

51. Standaert FE, Chew BP, Wong TS (1990) Influence of blood monocytes and lymphocytes on progesterone production by granulosa cells from small and large follicles in the pig. Am J Reprod Immunol 22: 49-55.

52. Standaert FE, Zamora CS, Chew BP (1991) Quantitative and qualitative changes in blood leukocytes in the porcine ovary. Am J Reprod Immunol 23: 159168.

53. Halme J, Hammond MG, Syrop CH, Talbert LM (1985) Peritoneal macrophages modulate human granulosa-luteal cell progesterone production. J Clin Endocrinol Metab (61) 912-916.

54. Yamanouchi K, Matsuyama S, Nishihara M, Shiota K, Tachi C, Takahashi M (1992) Splenic macrophages enhance prolactin-induced progestin secretion from mature granulosa cells in vitro. Biol Reprod 46: 1109-1113. 